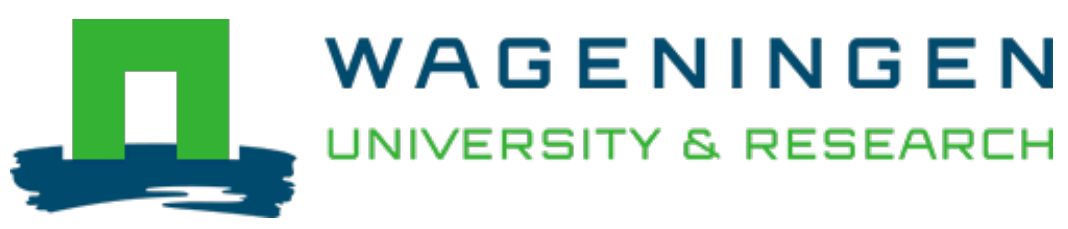

\title{
Development of defined mixed-culture fungal fermentation starter granulate for controlled production of rice wine
}

\author{
Innovative Food Science and Emerging Technologies \\ Ngo Thi Phuong Dung, N.T.P.; Rombouts, F.M.; Nout, M.J.R. \\ https://doi.org/10.1016/j.ifset.2005.04.007
}

This publication is made publicly available in the institutional repository of Wageningen University and Research, under the terms of article $25 \mathrm{fa}$ of the Dutch Copyright Act, also known as the Amendment Taverne. This has been done with explicit consent by the author.

Article 25 fa states that the author of a short scientific work funded either wholly or partially by Dutch public funds is entitled to make that work publicly available for no consideration following a reasonable period of time after the work was first published, provided that clear reference is made to the source of the first publication of the work.

This publication is distributed under The Association of Universities in the Netherlands (VSNU) 'Article $25 \mathrm{fa}$ implementation' project. In this project research outputs of researchers employed by Dutch Universities that comply with the legal requirements of Article $25 \mathrm{fa}$ of the Dutch Copyright Act are distributed online and free of cost or other barriers in institutional repositories. Research outputs are distributed six months after their first online publication in the original published version and with proper attribution to the source of the original publication.

You are permitted to download and use the publication for personal purposes. All rights remain with the author(s) and / or copyright owner(s) of this work. Any use of the publication or parts of it other than authorised under article $25 \mathrm{fa}$ of the Dutch Copyright act is prohibited. Wageningen University \& Research and the author(s) of this publication shall not be held responsible or liable for any damages resulting from your (re)use of this publication.

For questions regarding the public availability of this publication please contact openscience.library@wur.nl 


\title{
Development of defined mixed-culture fungal fermentation starter granulate for controlled production of rice wine
}

\author{
N. T. P. Dung ${ }^{\mathrm{a}}$, F. M. Rombouts ${ }^{\mathrm{b}}$, M. J. R. Nout ${ }^{\mathrm{b}, *}$ \\ aiotechnology Research and Development Institute, Can Tho University, Can Tho City, Vietnam \\ ${ }^{\mathrm{b}}$ Laboratory of Food Microbiology, Department of Agrotechnology and Food Sciences, \\ Wageningen University, P.O. Box 8129, 6700 EV Wageningen, The Netherlands
}

Received 16 February 2005; accepted 24 April 2005

\begin{abstract}
As a first step in the development of defined fungal starter granules for controlled winemaking from purple glutinous rice, the interaction of moulds and yeasts isolated from Vietnamese rice wine starters and the effect of some representative oriental herbs on the growth of moulds and yeasts were examined. Amylomyces rouxii and Saccharomyces cerevisae were shown to be compatible in mixed cultures, and the herbs "Tieu Hoi" (Fennel: Foeniculum vulgare Miller) and "Dinh Huong” (Clove: Syzygium aromaticum L.) which are used as supplementary ingredients by some local starter producers, were observed to stimulate the mould and yeast growth. Based on traditional starter manufacturing methods and modified on the basis of optimization experiments, a laboratory-scale manufacturing process for defined mixed-culture starter granules was established. In accordance with the national standard method, the wine produced with new experimental starter granules was found to have superior flavour and overall acceptability, compared with local commercial rice wines.
\end{abstract}

(C) 2005 Elsevier Ltd. All rights reserved.

Keywords: Moulds; Yeasts; Amylomyces; Saccharomyces; Oriental herbs; Starter granules; Winemaking; Rice wine

Industrial relevance: One of the major problems faced by commercial brewers of rice wine in Vietnam, is the variable quality and performance of the traditional starter tablets that are commonly used. The relevance of the present paper is that a stable, granulated starter has been developed, containing a defined mixture of mould and yeast cultures. This has proven to be shelf stable for more than 3 months, producing a very well accepted quality of wine.

\section{Introduction}

The Mekong Delta of Vietnam is a production area of a variety of food products, including wine made from purple glutinous rice. This wine differs from regular rice wine by its sherry-like taste and flavour, and its attractive brown-red colour. The principle of rice wine manufacture consists of the saccharification of steamed rice starch by fungal enzymes and the simultaneous or subsequent alcoholic fermentation by yeasts from traditional starter

\footnotetext{
* Corresponding author. Fax: +31 317484978

E-mail address: rob.nout@wur.nl (M.J.R. Nout).
}

tablets (Lotong, 1998; Nout \& Aidoo, 2002). The limited knowledge about the microbiological composition of traditional starters in relation to their performance in the fermentation poses an obstacle to industrial development, and thus the development of defined starters containing mixed pure cultures is a priority in food microbiology and technology research (Holzapfel, 1997; Ray, 2001; Zorba, Hancioglu, Genc, Karapinar, \& Ova, 2003).

Each local producer may have a different way of starter production, depending on available ingredients and local custom. During the preparation of starter tablets, the ingredients-rice flour, cassava flour or their mixturesare ground and thoroughly mixed with spices and herbs 
that are believed to prevent the growth of undesirable micro-organisms. The recipes are kept secret and are passed on from one generation to the next. Three main kinds of Vietnamese traditional starters can be distinguished (Luong, 1998; Phuc, 1998): (a) without and (b) supplemented with oriental herbs, preferred in the Mekong Delta, and (c) supplemented with leaves containing aromatic essential oils which are preferred in the mountainous districts. Water is then added to form a dough-like mass with a moisture content of $55-60 \%$, and this is inoculated using dry powdered starter from previous batches, followed by thorough mixing. The inoculated dough is shaped into small flattened or ball-shaped cakes about $4 \mathrm{~cm}$ in diameter and $1 \mathrm{~cm}$ thick. These are then covered with a thin layer of rice husks; according to producers this would reduce overheating and facilitate aeration. The incubation takes place on a bamboo tray in a ventilated place, at ambient temperature (about $30^{\circ} \mathrm{C}$ ) for 4 days during which drying also occurs. The tablets are now available to be used as inocula in winemaking. These commercial undefined starters have a shelf-life of several months; their activity varies considerably and therefore no prediction or guarantee can be given about the yield and quality of wine.

Nowadays, the quality of traditional fermented ricebased products including rice wine is preferably examined professionally using officially acknowledged and standardized techniques. Among the variety of methods to examine and evaluate wine, sensory evaluation and acceptability tests, such as the Vietnamese standard method 3215-79 formulated by the National Committee for Sensory Evaluation for the quality of food products, is applied currently.

For the successful manufacture of rice wine it is essential to dispose of a defined starter culture. Fungimoulds and yeasts-are the essential micro-organisms active in such starters, responsible for starch degradation and alcoholic fermentation, respectively. With the aim of upgrading the traditional starter tablet technology for winemaking, traditional starter tablets were compared and functional micro-organisms were isolated (Dung, Rombouts, \& Nout, unpubl. data, in press). A total of 104 microbial isolates, comprising 53 moulds and 51 yeasts, isolated from six selected fermentation starters were examined for their properties and optimum conditions for starch saccharification and alcohol production. The objectives of the present study were (a) to examine the mutual compatibility of selected enzymatically active moulds and high-glucose fermenting yeasts in mixed culture starter production, (b) to investigate the technical feasibility of preparing stable defined mixed culture starters containing selected compatible fungal strains, by appropriate modifications of the traditional starter manufacturing method, and (c) to evaluate the wine produced with such experimental starter granules, in comparison with representative rice wines.

\section{Materials and methods}

\subsection{Micro-organisms and preparation of inocula}

\subsubsection{Cultures}

Three mould strains, i.e. Rhizopus oryzae strain no. 15.2 (further referred to as M1); Amylomyces aff. rouxii strain no. 20.2, deposited as CBS 111760 (M2) and Amylomyces rouxii strain no. 20.3, deposited as CBS 111757 (M3) and one yeast, Saccharomyces cerevisae strain no. 2.1, deposited as LU1250 (Y) were used. These strains were isolated previously (Dung et al., unpubl. data) from Vietnamese traditional rice wine fermentation starters and selected (Dung et al., in press) for their ability to degrade starch and accumulate alcohol, respectively. Yeast was grown at $30{ }^{\circ} \mathrm{C}$ for 2 days on slants of Malt Extract Agar (MEA, Oxoid, CM59) and moulds for 5 days at $30{ }^{\circ} \mathrm{C}$ on the same medium. Grown cultures were maintained at $4{ }^{\circ} \mathrm{C}$. CBS: CentraalBureau voor Schimmelcultures, Utrecht, the Netherlands; LU: Wageningen University, the Netherlands.

\subsubsection{Preparation of inocula}

Inoculum suspensions were made by adding $5 \mathrm{~mL}$ of sterile physiological salt solution $(0.85 \% \mathrm{w} / \mathrm{v} \mathrm{NaCl})$ onto each pure culture slant. The biomass was gently scraped off the agar by means of an inoculation loop. For mould inoculation all of the suspension (approximately $4 \mathrm{~mL}$ ) prepared from one slant was used, and for yeast inoculation $1 \mathrm{~mL}$ of a suspension was applied.

\subsection{Effect of oriental herbs on microbial growth}

\subsubsection{Preparation of sterile herb extract}

Ten representative oriental herbs used in this study are listed in Table 1. Of each tested herb, $5 \mathrm{~g}$ was added to 100 $\mathrm{mL}$ of distilled water and extraction was done in a waterbath at $50{ }^{\circ} \mathrm{C}$ for $1 \mathrm{~h}$. The extract was filtered through a filter paper and a $0.2 \mu \mathrm{m}$ (Schleicher and Schuell, FP 30/0.2 CA-S) sterile membrane filter. Mixtures of extracts were made by pooling equal volumes of selected herb extracts.

\subsubsection{Effect of oriental herbs}

A liquid medium (see Section 2.3) was used. To $50 \mathrm{~mL}$ of this medium, $1 \mathrm{~mL}$ of sterile herb extract, corresponding to $50 \mathrm{mg}$ herb or herb mixture, was added. The following extracts were tested: A (equal proportions of herbs 1, 2, and 3, see Table 1), B (4, 5, and 6), C (7, 8, 9, and 10), D (all 10 listed herbs), E (only 7), F (only 8), G (only 9), H (only 10); a control without herb extract was included. Inoculation combinations included Y (S. cerevisae), M3 (A. rouxii), YM3 (S. cerevisae and A. rouxii) and an uninoculated control. Incubation was at $30{ }^{\circ} \mathrm{C}$ for $48 \mathrm{~h}$. 
Table 1

Oriental herbs used in the manufacture of Vietnamese rice wine starter tablets $^{\mathrm{a}}$

\begin{tabular}{|c|c|c|c|c|}
\hline No. & $\begin{array}{l}\text { Vietnamese } \\
\text { name }\end{array}$ & $\begin{array}{l}\text { English/ } \\
\text { common } \\
\text { name }\end{array}$ & Scientific name & $\begin{array}{l}\text { Part used for } \\
\text { extraction }\end{array}$ \\
\hline 1 & $\begin{array}{l}\text { Nhuc dau } \\
\text { khau }\end{array}$ & Mace & $\begin{array}{l}\text { Myristica } \\
\text { fragrans Houtt }\end{array}$ & Seed \\
\hline 2 & Bach truat & Bai zhu & $\begin{array}{l}\text { Atractylodes } \\
\text { macrocephala } \\
\text { Koidz }\end{array}$ & Tuber \\
\hline 3 & Nhuc que & $\begin{array}{l}\text { Cinnamon } \\
\text { twig }\end{array}$ & $\begin{array}{l}\text { Cinnamomum } \\
\text { cassia Blume }\end{array}$ & Outer bark \\
\hline 4 & Thao qua & Cardamom & $\begin{array}{l}\text { Amomum tsao-ko } \\
\text { Crev. et Lem. }\end{array}$ & Seed \\
\hline 5 & Cam thao & $\begin{array}{l}\text { Licorice } \\
\text { root }\end{array}$ & $\begin{array}{l}\text { Glycyrrhiza } \\
\text { uralensis } \text { Fish }\end{array}$ & Root \\
\hline 6 & Bac ha & Mint & $\begin{array}{l}\text { Mentha } \\
\text { arvensis L. }\end{array}$ & Leaf \\
\hline 7 & Te $\tan$ & Ginger & $\begin{array}{l}\text { Asarum } \\
\text { sieboldii Miq. }\end{array}$ & Root and leaf \\
\hline 8 & Uat kim & Turmeric & Curcuma longa $\mathrm{L}$. & Tuber \\
\hline 9 & Tieu hoi & Fennel & $\begin{array}{l}\text { Foeniculum } \\
\text { vulgare Miller }\end{array}$ & Flower \\
\hline 10 & $\begin{array}{l}\text { Dinh } \\
\text { huong }\end{array}$ & Clove & $\begin{array}{l}\text { Syzygium } \\
\text { aromaticum } \mathrm{L} .\end{array}$ & Flower \\
\hline
\end{tabular}

${ }^{\mathrm{a}}$ Based on data of (Loi, 2001) and information from local traders.

\subsection{Compatibility of moulds and yeasts}

\subsubsection{Steamed rice}

Any inhibitory or stimulatory effects of the yeast on the individual moulds were detected as follows. Purple glutinous rice $(50 \mathrm{~g})$ was soaked for $4 \mathrm{~h}$ at $22^{\circ} \mathrm{C}$ with distilled water $(60$ $\mathrm{mL}$ ) in a $250 \mathrm{~mL}$ conical flask covered by a cotton plug. After soaking, the mixture was steamed in an autoclave for $1 \mathrm{~h}$ at $100{ }^{\circ} \mathrm{C}$. The steamed rice was cooled to $35-40{ }^{\circ} \mathrm{C}$, then inoculated with pure cultures (see Section 2.1) and mixed. Three single cultures and three combinations of cultures, including M1, M2, M3, M1Y, M2Y, M3Y as well as a control without inoculum, were incubated for 3 days at $30^{\circ} \mathrm{C}$.

\subsubsection{Liquid medium}

To detect any positive or negative effect of the moulds on yeast, we used $50 \mathrm{~mL}$ of liquid medium containing $20 \%$ glucose, $1 \%$ yeast extract and $0.2 \%\left(\mathrm{NH}_{4}\right)_{2} \mathrm{SO}_{4}$, which was sterilized at $115{ }^{\circ} \mathrm{C}$ for $10 \mathrm{~min}$ in a $250 \mathrm{~mL}$ conical flask covered by a cotton plug. Mould and yeast suspensions (see Section 2.1) were inoculated into cooled $\left(35-40{ }^{\circ} \mathrm{C}\right)$ sterile medium. The single yeast culture and three combinations: $\mathrm{Y}$, YM1, YM2, YM3 as well as a control without inoculum, were tested. Incubation was at $30^{\circ} \mathrm{C}$ for 3 days under a water lock.

\subsection{Production of starter granules}

\subsubsection{Preparation of mixed flours and adjustment of required moisture content}

Rice flour was prepared from polished white rice using a hammer-mill (SM 100 confort, Retsch, Germany) to pass a
$0.25 \mathrm{~mm}$ sieve. Cassava flour was prepared as follows: fresh cassava tubers were peeled, chopped into small pieces, washed, sun-dried and ground into flour using the same mill.

A volume of sterile water was added to mixed rice and cassava flours, followed by additions of herb extract, and inoculum suspensions of yeast and mould cultures, to reach the required moisture content according to the following equation:

$\mathrm{MC}_{\mathrm{D}}=\frac{\left(\mathrm{MC}_{\mathrm{R}} * M_{\mathrm{R}}\right)+\left(\mathrm{MC}_{\mathrm{C}} * M_{\mathrm{C}}\right)+M_{(\mathrm{W}+\mathrm{H}+\mathrm{Y}+\mathrm{M})}}{M_{\mathrm{R}}+M_{\mathrm{C}}+M_{(\mathrm{W}+\mathrm{H}+\mathrm{Y}+\mathrm{M})}}$

in which $\mathrm{MC}=$ moisture content $(\mathrm{g} / \mathrm{g}), M=$ mass $(\mathrm{g})$, $\mathrm{D}=$ dough, $\mathrm{R}=$ rice flour, $\mathrm{C}=$ cassava flour, $\mathrm{W}=$ water, $\mathrm{H}=$ herb extract, $\mathrm{Y}=$ yeast incoculum suspension, $\mathrm{M}=$ mould inoculum suspension.

\subsubsection{Effects of mixing ratios and dry heat treatments of rice and cassava flours}

$50 \mathrm{~g}$ of mixed rice and cassava flours in a $250 \mathrm{~mL}$ conical flask covered by a cotton plug were heated in an electric oven overnight $(17 \mathrm{~h})$. The experiment comprised 18 combination treatments of different mixing ratios and different dry heating temperatures, as shown in Table 2 . The heated flour mixtures were allowed to cool to $35-40{ }^{\circ} \mathrm{C}$, and the required volume of sterile water was calculated (Eq. (1)) and added to reach the desired moisture content of $50 \%$ w/w. To the resulting mixed flours, $1 \mathrm{~mL}$ of sterile herb extract was added, and the mixture was inoculated with 8 $\mathrm{mL}$ mould suspension and $2 \mathrm{~mL}$ of yeast suspension. The inoculated dough with final moisture content of $55 \% \mathrm{w} / \mathrm{w}$ was mixed and incubated at $30{ }^{\circ} \mathrm{C}$ for $24 \mathrm{~h}$. Each treatment had two duplicates.

\subsubsection{Effect of mixed flour moisture content and incubation time in winemaking}

$40 \mathrm{~g}$ of rice flour and $10 \mathrm{~g}$ of cassava flour in a $250 \mathrm{~mL}$ conical flask covered by a cotton plug were heated at $100{ }^{\circ} \mathrm{C}$ in an electric oven overnight. The heated flour mixture was cooled to $35-40{ }^{\circ} \mathrm{C}$ and the mixed flour moisture contents of $40 \%, 50 \%, 60 \%$ and $70 \% \mathrm{w} / \mathrm{w}$ were prepared. To the mixtures was added: $1 \mathrm{~mL}$ of sterile herb extract, $8 \mathrm{~mL}$ of mould and $2 \mathrm{~mL}$ of yeast suspension. The inoculated doughs with final moisture contents of $47 \%, 55 \%, 63 \%$ and $72 \% \mathrm{w} / \mathrm{w}$, respectively, were mixed and incubated at $30{ }^{\circ} \mathrm{C}$ for different periods of 24, 48 and $72 \mathrm{~h}$. Each treatment had triplicates.

For preparation of wine using fermented dough as a starter, $50 \mathrm{~g}$ of purple glutinous rice and $60 \mathrm{~mL}$ of distilled water in a $250 \mathrm{~mL}$ conical flask covered by a cotton plug were soaked for $4 \mathrm{~h}$ at $25{ }^{\circ} \mathrm{C}$. After soaking the rice was steamed in an autoclave for $1 \mathrm{~h}$ at $100{ }^{\circ} \mathrm{C}$. The gelatinized rice was cooled to $35-40{ }^{\circ} \mathrm{C}$, then inoculated with $2 \mathrm{~g}$ of fermented dough and mixed. After solid-state fermentation during 2 days at $30{ }^{\circ} \mathrm{C}, 70 \mathrm{ml}$ of sterile water was added to the moulded mass to facilitate submerged alcoholic fermen- 
Table 2

Effect of mixing ratio and dry heating temperature of mixed flours of rice and cassava: experimental treatments and microbiological composition

\begin{tabular}{|c|c|c|c|c|c|c|c|c|c|}
\hline \multirow[t]{3}{*}{ No. } & \multicolumn{2}{|c|}{ Mixing ratio $(\%)$} & \multirow{3}{*}{$\begin{array}{l}\text { Dry heating } \\
\text { temperature }\left({ }^{\circ} \mathrm{C}\right)\end{array}$} & \multicolumn{6}{|c|}{ Microbiological composition (log $\mathrm{cfu} \mathrm{g}^{-1}$ of fermented dough) } \\
\hline & \multirow[t]{2}{*}{ Rice } & \multirow[t]{2}{*}{ Cassava } & & \multicolumn{3}{|c|}{ Incubation time $0 \mathrm{~h}$} & \multicolumn{3}{|c|}{ Incubation time $24 \mathrm{~h}$} \\
\hline & & & & Mould & Yeast & Bacteria & Mould & Yeast & Bacteria \\
\hline 1 & 100 & 0 & 60 & $4.7^{\mathrm{a}}$ & 6.5 & $2.1 \mathrm{kl}^{\mathrm{b}}$ & $5.5 \mathrm{fgh}$ & $7.9 \mathrm{bc}$ & $4 \mathrm{fg}$ \\
\hline 2 & 100 & 0 & 80 & 4.6 & 6.6 & 21 & $5.3 \mathrm{~h}$ & $8 \mathrm{abc}$ & $4 \mathrm{fg}$ \\
\hline 3 & 100 & 0 & 100 & 4.6 & 6.5 & $1.7 \mathrm{~m}$ & $5.9 \mathrm{abc}$ & $8.1 \mathrm{ab}$ & $3.7 \mathrm{hi}$ \\
\hline 4 & 80 & 20 & 60 & 4.7 & 6.5 & $2.8 \mathrm{ghi}$ & $5.3 \mathrm{~h}$ & $7.9 \mathrm{bc}$ & $4.5 \mathrm{~cd}$ \\
\hline 5 & 80 & 20 & 80 & 4.7 & 6.6 & $2.7 \mathrm{hi}$ & $5.7 \mathrm{def}$ & $8.1 \mathrm{ab}$ & $4.3 \mathrm{de}$ \\
\hline 6 & 80 & 20 & 100 & 4.6 & 6.5 & $2.3 \mathrm{k}$ & $6 \mathrm{ab}$ & $8.2 \mathrm{a}$ & $4 \mathrm{fg}$ \\
\hline 7 & 60 & 40 & 60 & 4.5 & 6.5 & $3.1 \mathrm{ef}$ & $5.6 \mathrm{efg}$ & $7.9 \mathrm{bc}$ & $4 \mathrm{fg}$ \\
\hline 8 & 60 & 40 & 80 & 4.7 & 6.6 & $2.9 \mathrm{fgh}$ & $5.7 \mathrm{def}$ & $7.9 \mathrm{bc}$ & $3.9 \mathrm{gh}$ \\
\hline 9 & 60 & 40 & 100 & 4.6 & 6.5 & $2.6 \mathrm{i}$ & $6 a b$ & 8 abc & $3.6 \mathrm{i}$ \\
\hline 10 & 40 & 60 & 60 & 4.6 & 6.5 & $3.4 \mathrm{~cd}$ & $5.3 \mathrm{~h}$ & $7.6 \mathrm{~d}$ & $4.6 \mathrm{bc}$ \\
\hline 11 & 40 & 60 & 80 & 4.5 & 6.6 & $3.3 \mathrm{de}$ & $5.5 \mathrm{fgh}$ & $7.9 \mathrm{bc}$ & 4.2 ef \\
\hline 12 & 40 & 60 & 100 & 4.6 & 6.6 & $3 \mathrm{fg}$ & $5.8 \mathrm{cde}$ & 8 abc & $4 \mathrm{fg}$ \\
\hline 13 & 20 & 80 & 60 & 4.7 & 6.5 & $3.9 \mathrm{a}$ & $5.5 \mathrm{fgh}$ & $7.9 \mathrm{bc}$ & $5 \mathrm{a}$ \\
\hline 14 & 20 & 80 & 80 & 4.6 & 6.6 & $3.6 \mathrm{bc}$ & $5.8 \mathrm{cde}$ & 8 abc & $4.8 \mathrm{ab}$ \\
\hline 15 & 20 & 80 & 100 & 4.5 & 6.5 & $3.5 \mathrm{~cd}$ & $6.1 \mathrm{a}$ & $8 a b c$ & $4.2 \mathrm{ef}$ \\
\hline 16 & 0 & 100 & 60 & 4.6 & 6.6 & $3.9 \mathrm{a}$ & $5.4 \mathrm{gh}$ & $7.8 \mathrm{~cd}$ & $5 \mathrm{a}$ \\
\hline 17 & 0 & 100 & 80 & 4.6 & 6.6 & $3.8 \mathrm{ab}$ & $6 \mathrm{ab}$ & $8 a b c$ & $5 \mathrm{a}$ \\
\hline 18 & 0 & 100 & 100 & 4.6 & 6.5 & $3.4 \mathrm{~cd}$ & $6 a b$ & $8.1 \mathrm{ab}$ & $4.5 \mathrm{~cd}$ \\
\hline
\end{tabular}

${ }^{\text {a }}$ Values are means of duplicates.

b Means with different subscripts within a column are statistically different at the $95 \%$ confidence level.

tation during 3 days at $30{ }^{\circ} \mathrm{C}$ under a water lock. Each treatment had triplicates.

\subsubsection{Granulation of starter dough, and drying conditions to obtain starter granules}

$120 \mathrm{~g}$ rice flour and $50 \mathrm{~g}$ cassava flour in a $500 \mathrm{~mL}$ conical flask covered by a cotton plug were heated at 100 ${ }^{\circ} \mathrm{C}$ in an electric oven overnight. The heated flour mixture was cooled to $35-40{ }^{\circ} \mathrm{C}$, and the mixed flour moisture contents at 30 and $40 \% \mathrm{w} / \mathrm{w}$ were prepared. To each of the resulting mixture $3 \mathrm{~mL}$ of sterile herb extract was added, and $24 \mathrm{~mL}$ of mould and $6 \mathrm{~mL}$ of yeast suspension were inoculated, resulting in final dough moisture contents of $39 \%$ and $47 \% \mathrm{w} / \mathrm{w}$, respectively. The inoculated dough was mixed and incubated at $30{ }^{\circ} \mathrm{C}$ for $24 \mathrm{~h}$. The fermented starter dough was subsequently transformed into granules of 3-4 $\mathrm{mm}$ diameter size, by mild rotation on steel sieves (pore size $4 \mathrm{~mm}$ ) that had been previously disinfected with $70 \%$ ethanol. The granules were dehydrated in a ventilated oven (FED 115 , Binder, Germany) on perforated drying trays at 40 ${ }^{\circ} \mathrm{C}$ or $45{ }^{\circ} \mathrm{C}$ up to $5 \mathrm{~h}$ to $4-5 \% \mathrm{w} / \mathrm{w}$ final moisture content.

\subsubsection{Storage stability of dry starter granules}

For storage experiments, dry starter granules were vacuum packed in sterile polypropylene bags with 0.06 $\mathrm{mm}$ thickness using a "Vacupack plus" machine (Krups, type 380, CE, z260590, P.R.C.). Dried starter granules described above were stored under two different conditions: at $4{ }^{\circ} \mathrm{C}$ and at ambient temperature (approx. $30{ }^{\circ} \mathrm{C}$ ), both protected from daylight. Analyses were done after 0, 1, 2, and 3 months of storage.

\subsection{Winemaking and sensory evaluations}

The defined experimental starter was prepared following the flow diagram shown in Fig. 6. The dry starter granules had been stored at $4{ }^{\circ} \mathrm{C}$ for 2 weeks before they were used to produce wine.

Preparation of wine from purple glutinous rice was basically as described in Section 2.4. After the stage of alcoholic fermentation, a maturation period of 2 weeks was included. All of the fermented rice suspension was then homogenized using a Stomacher Lab-blender (Seward 400, Emergo, England), centrifuged (7500 rpm for $20 \mathrm{~min}$; Rotanta 46R, type 4810, Hettich Zentrifugen, D78532 Tuttingen, Germany) and clear supernatant wine was harvested.

This wine underwent sensory evaluation tests according to Vietnamese standard method 3215-79 (Thu, 1989). Depending on the kind of product, quality attributes are allocated a weight factor illustrating their perceived importance for the acceptability of the product. At first, panelists will score individual quality attributes using a scale of $0-5$. Scores for a certain attribute given by all panelists are averaged, and the average is corrected using the corresponding weight factor. Subsequently, the weighted average scores are totaled. Table 3 describes quality criteria categories, weight factors, and scoring ranges applicable to sensory evaluation of rice wine according to the method used. 
Table 3

Quality criteria categories, weight factors, and scoring ranges applicable to sensory evaluation of rice wine according to Vietnamese standard 3215-79 (Thu, 1989)

\begin{tabular}{|c|c|c|c|}
\hline Criterion & $\begin{array}{l}\text { Weight } \\
\text { factor }\end{array}$ & $\begin{array}{l}\text { Scoring range } \\
\text { (unweighted) }\end{array}$ & Description of scores \\
\hline \multirow[t]{6}{*}{$\begin{array}{r}\text { Colour and } \\
\text { clearness }\end{array}$} & \multirow[t]{6}{*}{0.8} & 5 & $\begin{array}{l}\text { Liquid is very clear, no turbidity, } \\
\text { no unusual small objects, colour is } \\
\text { perfectly specific for the product }\end{array}$ \\
\hline & & 4 & $\begin{array}{l}\text { Liquid is very clear, no turbidity, } \\
\text { a little bit of unusual small objects, } \\
\text { colour is specific for the product }\end{array}$ \\
\hline & & 3 & $\begin{array}{l}\text { Liquid is clear, more unusual small } \\
\text { objects, colour is a bit different } \\
\text { from the specific colour of } \\
\text { the product }\end{array}$ \\
\hline & & 2 & $\begin{array}{l}\text { Liquid is rather turbid, contains } \\
\text { many unusual small objects, colour } \\
\text { is very different from the specific } \\
\text { colour of the product }\end{array}$ \\
\hline & & 1 & $\begin{array}{l}\text { Liquid is turbid, containing much } \\
\text { sediment, many unusual crude } \\
\text { objects, the colour is not specific } \\
\text { for the product }\end{array}$ \\
\hline & & 0 & $\begin{array}{l}\text { Liquid is very turbid, the colour } \\
\text { is dirty, the product is spoiled }\end{array}$ \\
\hline \multirow[t]{6}{*}{ Flavour } & \multirow[t]{6}{*}{1.2} & 5 & $\begin{array}{l}\text { Fragrant, harmonious, perfectly } \\
\text { specific for the product }\end{array}$ \\
\hline & & 4 & $\begin{array}{l}\text { Not perfectly harmonious, fragrant } \\
\text { and perfectly specific for the } \\
\text { product but it takes time to realize }\end{array}$ \\
\hline & & 3 & $\begin{array}{l}\text { Slightly to strong undesirable } \\
\text { flavour, not very specific for } \\
\text { the product }\end{array}$ \\
\hline & & 2 & $\begin{array}{l}\text { Strong undesirable flavour, very } \\
\text { little specific for the product }\end{array}$ \\
\hline & & 1 & $\begin{array}{l}\text { Very strong and obviously } \\
\text { undesirable flavour, not specific for } \\
\text { the product }\end{array}$ \\
\hline & & 0 & $\begin{array}{l}\text { Unpleasant and undesirable flavour } \\
\text { of spoiled product }\end{array}$ \\
\hline \multirow[t]{6}{*}{ Taste } & \multirow[t]{6}{*}{2.0} & 5 & $\begin{array}{l}\text { Harmonious, gentle, excellent taste, } \\
\text { perfectly specific for the product }\end{array}$ \\
\hline & & 4 & $\begin{array}{l}\text { Not perfectly harmonious, good } \\
\text { taste, specific for the product }\end{array}$ \\
\hline & & 3 & $\begin{array}{l}\text { Not harmonious, fair taste, little } \\
\text { specific for the product }\end{array}$ \\
\hline & & 2 & $\begin{array}{l}\text { Bitter, pungent, weak taste, very } \\
\text { little specific for the product }\end{array}$ \\
\hline & & 1 & $\begin{array}{l}\text { Unpleasant and undesirable taste } \\
\text { of spoiled product }\end{array}$ \\
\hline & & 0 & $\begin{array}{l}\text { Product completely spoiled and } \\
\text { corrupt, impossible to taste }\end{array}$ \\
\hline
\end{tabular}

\begin{tabular}{lc} 
Quality category & $\begin{array}{l}\text { Total of } \\
\text { weighted scores }\end{array}$ \\
\hline Excellent & $19.6-20.0$ \\
Good & $18.2-19.5$ \\
Fair & $15.2-18.1$ \\
Acceptable & $11.2-15.1$ \\
Poor (not acceptable but can still be offered for sale) & $7.2-11.1$ \\
Very poor (not acceptable for sale but can possibly & $4.0-7.1$ \\
$\quad$ be used after appropriate reprocessing) & \\
Spoiled (impossible to use or to reprocess) & $0-3.9$ \\
\hline
\end{tabular}

The evaluation process was carried out in a temperaturecontrolled room at $20{ }^{\circ} \mathrm{C}$, using identical clean glassware, coded and numbered using tri-figures. Of each kind of wine a volume of $4 \mathrm{~L}$ used for testing was prepared in one big container, mixed and divided into $200 \mathrm{~mL}$ portions in bottles that had previously been rinsed with the corresponding wine. These small bottles had been coded and stored at $20{ }^{\circ} \mathrm{C}$ at least $2 \mathrm{~h}$ before testing. Twenty examiners who are well-experienced in sensory evaluation of wine were invited. The examiners were requested to have only a moderate meal at least $2 \mathrm{~h}$ before the sensory evaluation session, and from that time point to refrain from eating, smoking and using flavoured products such as perfumes, cosmetics and soap. Before tasting a sample, the examiners had to drink some mineral water. Colour, clearness, flavour and taste of the wine were evaluated by each examiner.

\subsection{Analytical methods}

\subsubsection{Microbiological analysis}

A sample of $10 \mathrm{~g}$ was transferred to a stomacher bag and homogenized with $90 \mathrm{~mL}$ sterile saline $(\mathrm{NaCl} 0.85 \% \mathrm{w} / \mathrm{v})$ in a Stomacher Lab-blender (Seward 400, Emergo, England) for $1 \mathrm{~min}$ at high speed, and appropriate serial dilutions were performed using the same diluent. 1-mL portions of the appropriately diluted suspension were mixed with molten $\left(45{ }^{\circ} \mathrm{C}\right)$ medium and made into pour-plates. Czapek-Dox Agar (Oxoid, CM95), Oxytetracycline Glucose Yeast Extract Agar (Oxoid, CM545) and Plate Count Agar (Oxoid, CM325) were used for mould, yeast, and total mesophilic counts, respectively. All plates were incubated at $30{ }^{\circ} \mathrm{C}$ for $2-4$ days. The colonies that appeared after incubation were counted, calculated as colony forming units (cfu) per gram of sample and expressed as $\log \mathrm{cfu}^{-1}$.

\subsubsection{Chemical analysis}

The $\mathrm{pH}$ was measured by digital $\mathrm{pH}$ meter WTW $\mathrm{pH}$ 525. Glucose contents were determined by glucose oxidase test kit (Megazyme, GLC 9/96). Amyloglucosidase was assayed by a test kit (Megazyme, RAMGR3) containing $p$-nitrophenyl- $\beta$-maltoside (McCleary, Bouhet, \& Driguez, 1991). Total alcohol content was determined by the distillation method (So \& Nhuan, 1991). Ethanol contents were determined by enzymatic analysis using an alcohol dehydrogenase kit (Boehringer, Mannheim, cat. no. 176290). Total dissolved solid content (mainly sugars) of saccharified liquid was estimated by measuring ${ }^{\circ} \mathrm{Brix}$ with a manual refractometer (FG102/112, Euromex-Holland). In liquid cultures, biomass was determined by the dry matter method.

\subsubsection{Statistical analysis}

Experimental data were analysed statistically using Statgraphics Plus Version 5, Manugistics, Inc., Rockville, USA. 


\section{Results and discussion}

\subsection{Interaction of mixed pure cultures}

The glucose and ethanol contents, amyloglucosidase activity and volumes of liquid produced by single moulds and by combinations of mould plus yeast, are presented in Fig. 1. Because of extensive liquefaction during the incubation, samples of liquid could be taken after 3 days of incubation at $30{ }^{\circ} \mathrm{C}$ for determination of $\mathrm{pH}$, volume of liquid produced, glucose, ethanol and amyloglucosidase activity. The uninoculated control did not show any changes in the properties mentioned above, during the incubation.

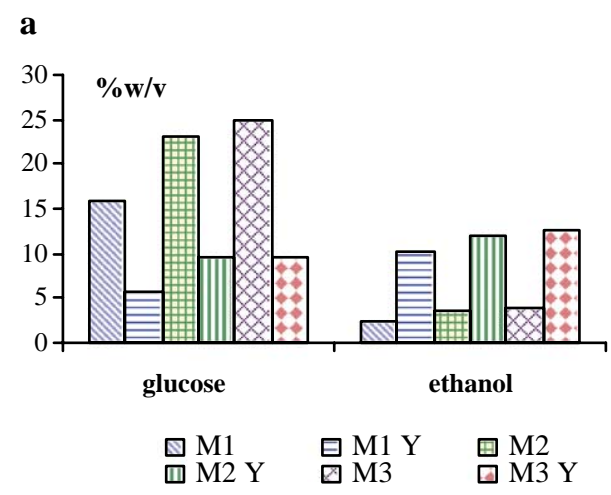

b
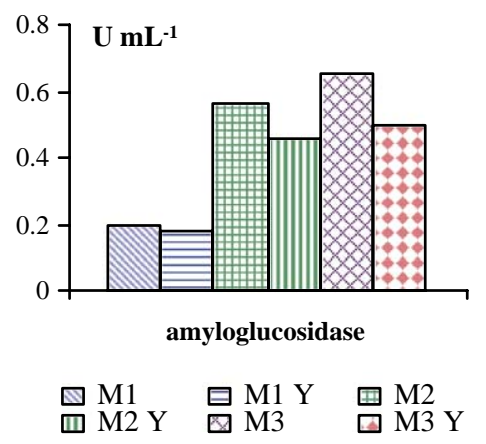

c

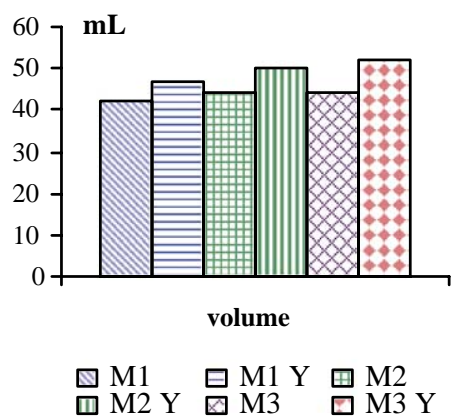

Fig. 1. The effects of yeast on liquefaction and saccharification of gelatinized purple glutinous rice starch by moulds. Each of three moulds namely Rhizopus oryzae (M1), Amylomyces aff. rouxii (M2) and Amylomyces rouxii (M3) were grown individually and in a mixed culture with yeast Saccharomyces cerevisae (Y). The samples were analysed after 3 days of incubation at $30^{\circ} \mathrm{C}$.
The $\mathrm{pH}$ values in all treatments showed a decrease from 6 to 4.2-4.6 after 3 days of incubation, which can be considered typical in solid-state fermentations by moulds and yeasts (Battcock \& Ali, 1993; Hesseltine, 1983). The results show that glucose levels in "mould-only" flasks were significantly higher (95\% confidence level) than in "mould plus yeast". Concomitantly, ethanol produced by mould only was significantly less than in mixed cultures of mould and yeast. In mixed cultures of mould and yeast, glucose produced by mould is consumed and fermented by yeast, into ethanol.

While all three moulds produced amyloglucosidase, $A$. rouxii strain 20.3 (M3) was the best producer of amyloglucosidase and glucose. All three moulds also produced a certain amount of ethanol under the low oxygen conditions of the experiment. This is a common feature of moulds belonging to the order of Mucorales (Hawker, 1966). The combination of this mould with $S$. cerevisae strain 2.1 (M3Y) also gave the highest alcohol concentration and the largest volume of free liquid. Somewhat less amyloglucosidase activity was produced by all three moulds in the presence of yeast (Fig. 1b), when (part of) the glucose was simultaneously fermented to ethanol (Fig. 1a). All three mould strains tested are compatible with the yeast strain, i.e. the moulds show the same saccharification and liquefaction ability in the presence of the yeast.

For effects of mould on yeast following the same principle of inoculation, the liquid medium (see Section 2.3) was inoculated with yeast only and with a combination of yeast and each of the three moulds. After 3 days of incubation at $30{ }^{\circ} \mathrm{C}$, samples were taken for determination of $\mathrm{pH}$, glucose, ethanol and biomass. The uninoculated control showed pH 6 and a glucose content of 19.2\% w/v, which was the same as in the initial situation. In the other flasks the $\mathrm{pH}$ value rapidly dropped to a constant value of 3.8-4.0, which may be expected in successful alcoholic fermentations (Hesseltine, 1983).

The ethanol contents and biomass produced are presented in Fig. 2. Ethanol produced by yeast only was significantly higher than by yeast plus mould $(95 \%$ confidence level). On the contrary, biomass formed by yeast only was significantly lower than biomass obtained with mixed cultures, especially with M1. These data indicate that both yeast and mould grew very well in the medium. However, when mould was present, it competed with yeast for glucose, resulting in lower ethanol in mixed cultures. Due to its very fast growth with thick mycelium, $R$. oryzae (M1) consumed relatively high amounts of glucose for mycelium production, yielding most biomass when present in a mixed culture. In contrast, the highest ethanol level $(9.6 \% \mathrm{w} / \mathrm{v})$ was obtained in the flask with yeast only, and ethanol contents produced by mixed cultures were in the range of $8.3-8.6 \% \mathrm{w} / \mathrm{v}$. While the yeast converts glucose mainly to ethanol and carbon dioxide, with production of moderate amounts of biomass, the moulds oxidise glucose 

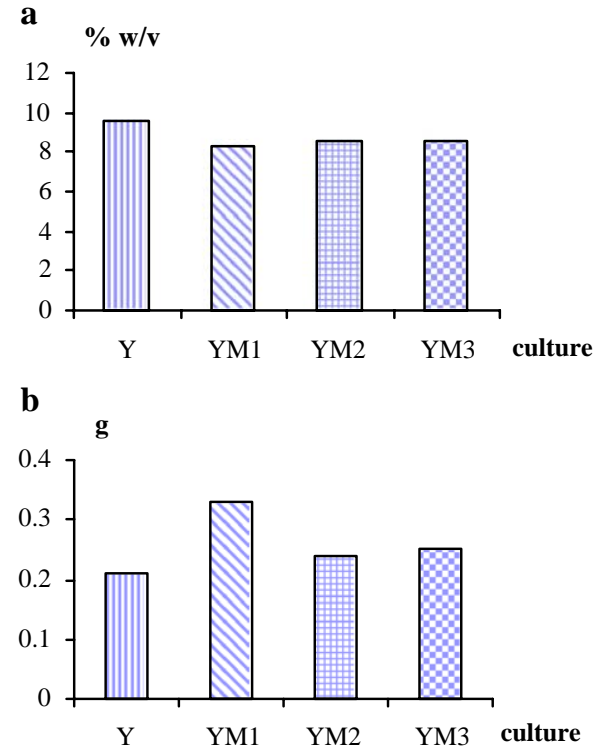

Fig. 2. The effects of moulds on (a) alcohol and (b) biomass formation of yeast. The yeast Saccharomyces cerevisae (Y) was grown in glucose medium singly and in mixed cultures with each of three moulds namely Rhizopus oryzae (YM1), Amylomyces aff. rouxii (YM2) and Amylomyces rouxii (YM3). Samples were taken and analysed after 3 days of incubation at $30{ }^{\circ} \mathrm{C}$.

for the greater part to carbon dioxide and water, which yields much more energy to produce biomass.

In conclusion, although competition for glucose was obvious, there were no combinations that really inhibited each other. Combining the results of "mould on yeast" and "yeast on mould" it can be concluded that the tested strains are compatible with each other and can be used as mixed culture.

\subsection{Effects of oriental herbs on microbial growth}

Based on the experience of leading local producers and limited literature references (Hieu, 1990; Loi, 2001), 10 representative oriental herbs were selected for this study. The aim was to find out whether any specific herb affects the growth of mould and yeast in dough during the production of rice wine fermentation starters.

Although these herbs are primarily added to starters to convey fragrant flavour to the rice wine, they may also have antibacterial properties, thereby protecting the rice wine fermentation against microbial spoilage or fermentation failure. This aspect was not included in our experiment.

Fig. 3 shows the effects of added herb extracts on biomass and viable count of the yeast and moulds, compared with a control without herbs. It can be concluded that herbs 9 and 10 present in extracts C, D, G, and $\mathrm{H}$ (cf. Table 1) have a stimulatory effect on biomass formation and yeast count. Particularly herb 9 (Foeniculum vulgare) has the strongest stimulatory effect. We did not investigate which chemical compound(s) in this aqueous extract of the flower (the part used for extraction) of this herb, commonly known as Fennel, cause this growth stimulation. Possibly the stimulation could be due to its mineral content, particularly its Magnesium, Manganese or other salt contents (Walker, 1998).

Both "Tieu Hoi" (F. vulgare) and "Dinh Huong" (Syzygium aromaticum) are commonly applied in the traditional process of rice winemaking in Vietnam, because of their fragrant flavour and assumed antibacterial properties. Because of their beneficial properties, both herbs were included in our design of defined starter cultures.

\subsection{Effects of mixing ratios and dry heat treatments of rice and cassava flours}

Rice and cassava flours can both be used as ingredients in the production of rice wine starters in Vietnam. Although the practical reasons for using rice and cassava are known (Luong, 1998), no published knowledge is available about the effect of mixing ratio. If only rice flour is used, the starter tablet becomes too compact and hard so that moulds can grow only on its surface. On the other hand, if only

$\mathbf{a}$

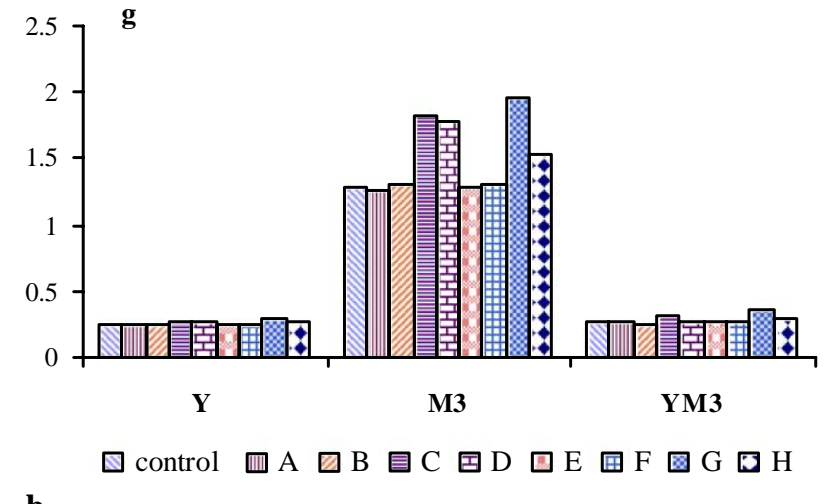

b

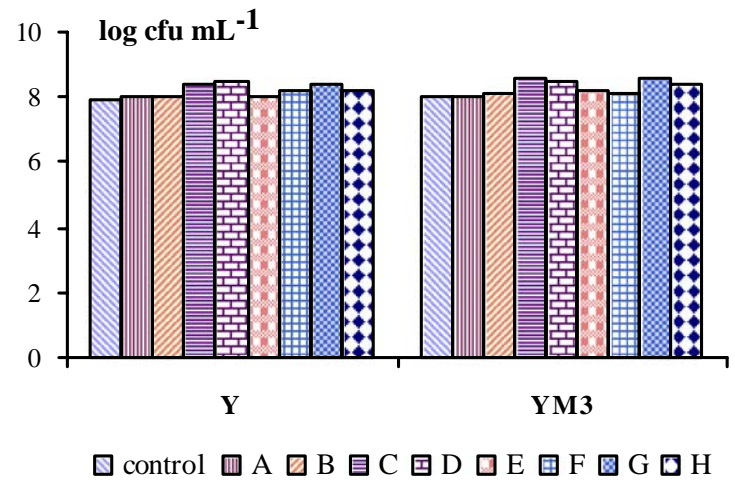

Fig. 3. The effect of oriental herbs on (a) the biomass of mould and yeast and (b) the yeast count. One control, and 8 treatments with herbs including A $(1+2+3), \mathrm{B}(4+5+6), \mathrm{C}(7+8+9+10), \mathrm{D}(1-10), \mathrm{E}(7), \mathrm{F}(8), \mathrm{G}(9)$, and $H(10)$. Numbers in brackets refer to the description of oriental herbs (cf. Table 1). After incubation at $30{ }^{\circ} \mathrm{C}$ for $48 \mathrm{~h}$ the growth of mould M3 (Amylomyces rouxii) was determined by biomass and the growth of yeast $\mathrm{Y}$ (Saccharomyces cerevisae) was determined by both biomass and viable count. 
cassava flour is used, the starter tablet becomes too soft and spongy, which is assumed to limit the growth of yeasts. Local starter producers prefer to use cassava as a supplement because it is cheap and combines well with rice flour. The dry heating of mixed flours at the start of the process is not a customary procedure, but was carried out by us with the aim to reduce the number of undesirable spoilage microorganisms during the further stages in the process of starter production. The effect of the mixing ratio and the dry heat treatment on the growth of various groups of microorganisms is shown in Table 2.

Although only pure cultures of mould and yeast were used to inoculate the starter dough, the count of mesophilic bacteria was also determined to detect the presence of contaminating bacteria. Due to the standardized preparation of inoculum, the mould and yeast counts at the onset of incubation were always approx. $4.6 \mathrm{log} \mathrm{cfu} \mathrm{g}^{-1}$ for mould and $6.5 \log \mathrm{cfu} \mathrm{g}^{-1}$ for yeast. A certain number of bacteria (ranging from 1.7 to $3.9 \mathrm{log} \mathrm{cfu}^{-1}$ ) was also found at the start of incubations, and these developed but kept to tolerable levels (3.6-5.0 log cfu $\mathrm{g}^{-1}$ ) after $24 \mathrm{~h}$ of incubation. Significantly higher levels of bacterial contamination were found when dry heat treatment was at lower temperatures, and especially with higher levels of cassava flour in the mixture. The latter effect may be explained by relatively high levels of bacterial contamination of cassava, particularly with heat-resistant species (Miambi, Guyot, \& Ampe, 2003).

Although some bacterial contamination was detectable, their levels were relatively low and mould and yeast growth was not impeded. After $24 \mathrm{~h}$, the levels developed up to 6.1 $\log \mathrm{cfu}^{-1}$ for mould, and $8.2 \log \mathrm{cfu} \mathrm{g}^{-1}$ for yeast. Neither the mixing ratio of flours, nor the temperatures of dry heating had a significant effect on yeast count, whereas only the dry heating temperature had a significant impact on mould growth. Mixed flours heated at $100{ }^{\circ} \mathrm{C}$ allowed for significantly higher levels of mould cfu than in flour heated at the lower temperatures. Although for moulds, numbers of cfu do not fully reflect the biomass formed, the effect of heating temperatures may be explained by a stronger reduction of competitive bacteria that otherwise would inhibit the growth of mould. The growth of yeast was not much affected by competitive undesirable bacteria during incubation, possibly because of its faster multiplication than that of the mould.

In conclusion, the dry heating temperature at $100{ }^{\circ} \mathrm{C}$ is successful in reducing the number of undesirable bacteria without overheating the rice and cassava flours-as judged by the absence of browning-and we applied it as a decontamination treatment in the process of starter production. The mixing ratio of $80 \%$ rice flour with $20 \%$ cassava flour was selected as appropriate, as both mould and yeast can grow very well with minimum competition from bacteria and the binding properties of cassava are best in this mixture. The dried starter granules should not be too soft or crumbly because this would lead to losses and dustiness when used in practice.

\subsection{Effect of mixed flour moisture content and incubation time}

The dough moisture content has been reported as an important parameter during the preparation of starch-based starters for alcoholic fermentation (Lotong, 1998; Steinkraus, Cullen, Pederson, Nellis \& Gavitt, 1983). It should be favourable for the growth of mould and yeast: too low or too high moisture contents may result in poor viability of cultures and to failure of fermentation processes. Therefore, we examined the effect of 4 dough moisture levels, i.e. $47 \%$, $55 \%, 63 \%$ and $72 \%$ as shown in Fig. 4. In commercial practice, a level of $50-55 \%$ is used. It appears that incubation periods beyond $24 \mathrm{~h}$ are not favourable for the

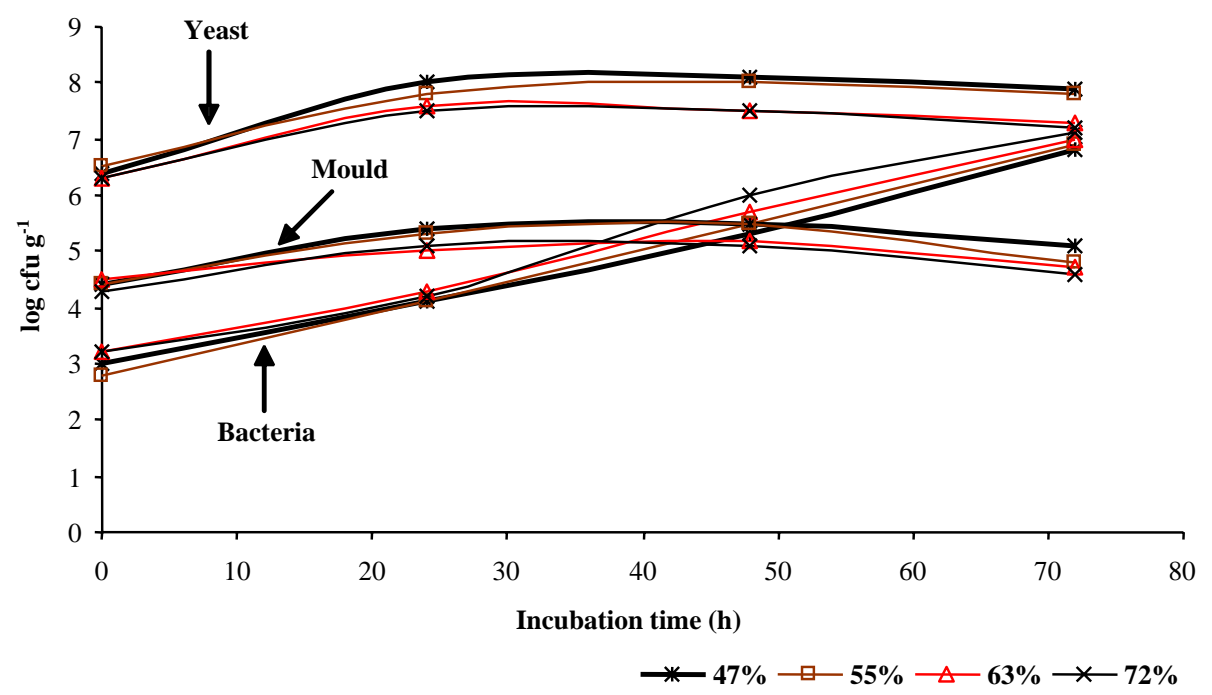

Fig. 4. The effect of mixed flour moisture content on microbiological composition of starter dough. The 4 dough moisture levels, i.e. $47 \%$, $55 \%$, $63 \%$ and $72 \%$ were examined. Samples of starter dough were taken at $0,24,48$ and $72 \mathrm{~h}$ of incubation for plate counts. 
composition of fermented dough. At $24 \mathrm{~h}$ of incubation, mould and yeast had reached maxima of 5 and $7-8 \log \mathrm{cfu}$ $\mathrm{g}^{-1}$, respectively. However, prolonged incubation for 48 and $72 \mathrm{~h}$ resulted in a slight decline of viable mould and yeast, with concomitant increase of undesirable bacteria. The levels of bacteria increased gradually during the incubation from 3 to $7 \log \mathrm{cfu}^{-1}$; at these levels we may expect bacteria to compete with the growth of desirable mould and yeast.

Fig. 4 also shows that the fungi tend to multiply best in dough of $47 \%$ moisture content, whereas bacterial growth is more successful at the higher moisture levels.

The doughs fermented during 24, 48 and $72 \mathrm{~h}$ were tested as starter in winemaking, and the wines were judged mainly by flavour and alcohol content. The count of mesophilic bacteria in the wine was also determined to examine the fate of bacteria which were present as starter contaminants. Table 4 shows that most doughs gave a pleasant flavour that was quite strong alcoholic, aromatic and sweet, except in one case $(72 \%$ moisture content, incubated for $72 \mathrm{~h}$ ) which gave a sour but only very slight alcoholic flavour. For all starter doughs, the wine alcohol contents were significantly lower with longer dough incubation times; starter dough of $47 \%$ moisture content showed significantly higher wine alcohol content especially after having been incubated for 24 or 48 h. Table 4 shows that a certain number of bacteria still remained in the final product, and that there was a positive correlation between the levels of bacteria in fermented dough and in the final wine, with significantly

Table 4

Winemaking performance and bacterial levels in starter doughs of different moisture contents, after incubation for different periods

\begin{tabular}{|c|c|c|c|c|c|c|}
\hline \multicolumn{3}{|c|}{ Starter dough } & \multicolumn{4}{|c|}{ Rice wine obtained } \\
\hline \multirow{2}{*}{$\begin{array}{l}\text { Moisture } \\
\text { content } \\
(\%)\end{array}$} & \multirow{2}{*}{$\begin{array}{l}\text { Incubation } \\
\text { period }(\mathrm{h})\end{array}$} & \multirow{2}{*}{$\begin{array}{l}\text { Flavour } \\
\text { assessment }^{\mathrm{a}}\end{array}$} & \multicolumn{2}{|c|}{ Alcohol content } & \multicolumn{2}{|c|}{ Mesophilic bacteria } \\
\hline & & & $(\% \mathrm{v} / \mathrm{v})$ & $\overline{\text { S.D. }}{ }^{\mathrm{b}}$ & $\begin{array}{l}\text { Log cfu } \\
\mathrm{g}^{-1} \text { of } \\
\text { fermented } \\
\text { dough }\end{array}$ & S.D. \\
\hline 47 & 24 & +++ & $19.8^{c} a^{d}$ & 1.1 & $4.6 \mathrm{~d}$ & 0.87 \\
\hline 47 & 48 & +++ & $19.8 \mathrm{a}$ & 0.26 & $6.2 \mathrm{c}$ & 0.44 \\
\hline 47 & 72 & +++ & $18.8 \mathrm{~b}$ & 0.36 & $7.2 \mathrm{ab}$ & 0.2 \\
\hline 55 & 24 & +++ & 19.8 a & 0.66 & $4.7 \mathrm{~d}$ & 0.26 \\
\hline 55 & 48 & +++ & $18.8 \mathrm{~b}$ & 0.35 & $6.3 \mathrm{c}$ & 0.44 \\
\hline 55 & 72 & ++ & $13.8 \mathrm{~d}$ & 0.72 & $7.5 \mathrm{a}$ & 0.44 \\
\hline 63 & 24 & +++ & $18.8 \mathrm{~b}$ & 0.26 & $4.7 \mathrm{~d}$ & 0.36 \\
\hline 63 & 48 & +++ & $18.8 \mathrm{~b}$ & 0.36 & $6.6 \mathrm{bc}$ & 0.52 \\
\hline 63 & 72 & ++ & $12.3 \mathrm{e}$ & 0.17 & $7.9 \mathrm{a}$ & 0.36 \\
\hline 72 & 24 & ++ & $18.8 \mathrm{~b}$ & 0.26 & $4.7 \mathrm{~d}$ & 0.26 \\
\hline 72 & 48 & ++ & $17.2 \mathrm{c}$ & 0.56 & $6.7 \mathrm{bc}$ & 0.53 \\
\hline 72 & 72 & + & $11.5 \mathrm{e}$ & 0.3 & $7.9 \mathrm{a}$ & 0.36 \\
\hline
\end{tabular}

${ }^{\text {a }}$ Flavour ranging from + (do not like much because of slightly alcoholic flavour and unpleasant flavour) to +++ (like very much for its strong alcoholic flavour and aromatic sweet smell).

${ }^{\mathrm{b}}$ Standard deviation.

${ }^{\mathrm{c}}$ Values are means of triplicates.

${ }^{d}$ Means with different subscripts are statistically different at the $95 \%$ confidence level. higher levels of bacteria in doughs of longer incubation times.

It appeared that the combination of $47 \%$ moisture content and short $(24 \mathrm{~h})$ dough incubation provided optimum conditions for the maximum development of functional fungi with minimized bacterial interference. An added advantage of the lower moisture content is that less water needs to be removed in the later stage of dehydration.

\subsection{Effect of granulation and dehydration on viability of functional fungi in a laboratory-scale starter production process}

In the previous section it was concluded that $47 \%$ moisture content (the lowest level tested) gave promising results with respect to microbiological composition and wine quality. In view of required drying, it would be of interest to apply even lower moisture levels. Therefore we compared doughs made at $39 \%$ and $47 \%$ moisture content for their behaviour during granulation, drying and the effect on fungal viability. Fermented dough granules were prepared and spread on a perforated drying tray to be dehydrated at 40 and $45{ }^{\circ} \mathrm{C}$ in an electric oven during periods up to $5 \mathrm{~h}$. Fig. 5 shows the changes of dry matter levels and viable counts of mould and yeast; with the combination of $39 \%$ moisture content and $45{ }^{\circ} \mathrm{C}$ drying temperature, the maximum dry matter content of $95 \%$ is reached in the shortest time ( $3 \mathrm{~h}$ of drying). Moisture of $39 \%$ or $47 \%$ and drying conditions did not significantly influence the number of fungal colony forming units. This indicates that the granulation results in a rapid drying; this is also favourable for the survival of the starter microorganisms.

In order to evaluate the viability of surviving fungi in the dried starter granules, they were tested for their winemaking performance. No significant optimum combination of processing factors was observed in relation with wine quality. All starter granules achieved normal and successful wine fermentation with adequate liquefaction after 2 days of solid-state fermentation, normal $\mathrm{pH}$ levels (4.4-4.5), typical flavour (strong alcohol and sweet smelling) and high alcohol contents of the final products $(18.8-19.7 \% \mathrm{v} / \mathrm{v})$.

Whereas no differences were observed in the performance of doughs of $39 \%$ and $47 \%$ moisture content, the advantage of the lower moisture content is that drying can be achieved more rapidly and cheaper, and that this (39\% m.c.) dough is less sticky and easier to granulate.

By consequence, for the preparation of dried granulated starter, the moisture level of $39 \%$ and drying temperature of $45^{\circ} \mathrm{C}$ were selected for further process developments.

\subsection{Effect of storage of dry starter granules on fungal viability}

Dry starter granules were vacuum packed and stored at 4 ${ }^{\circ} \mathrm{C}$ (refrigerator) and at approx. $30{ }^{\circ} \mathrm{C}$ (ambient tempera- 
a
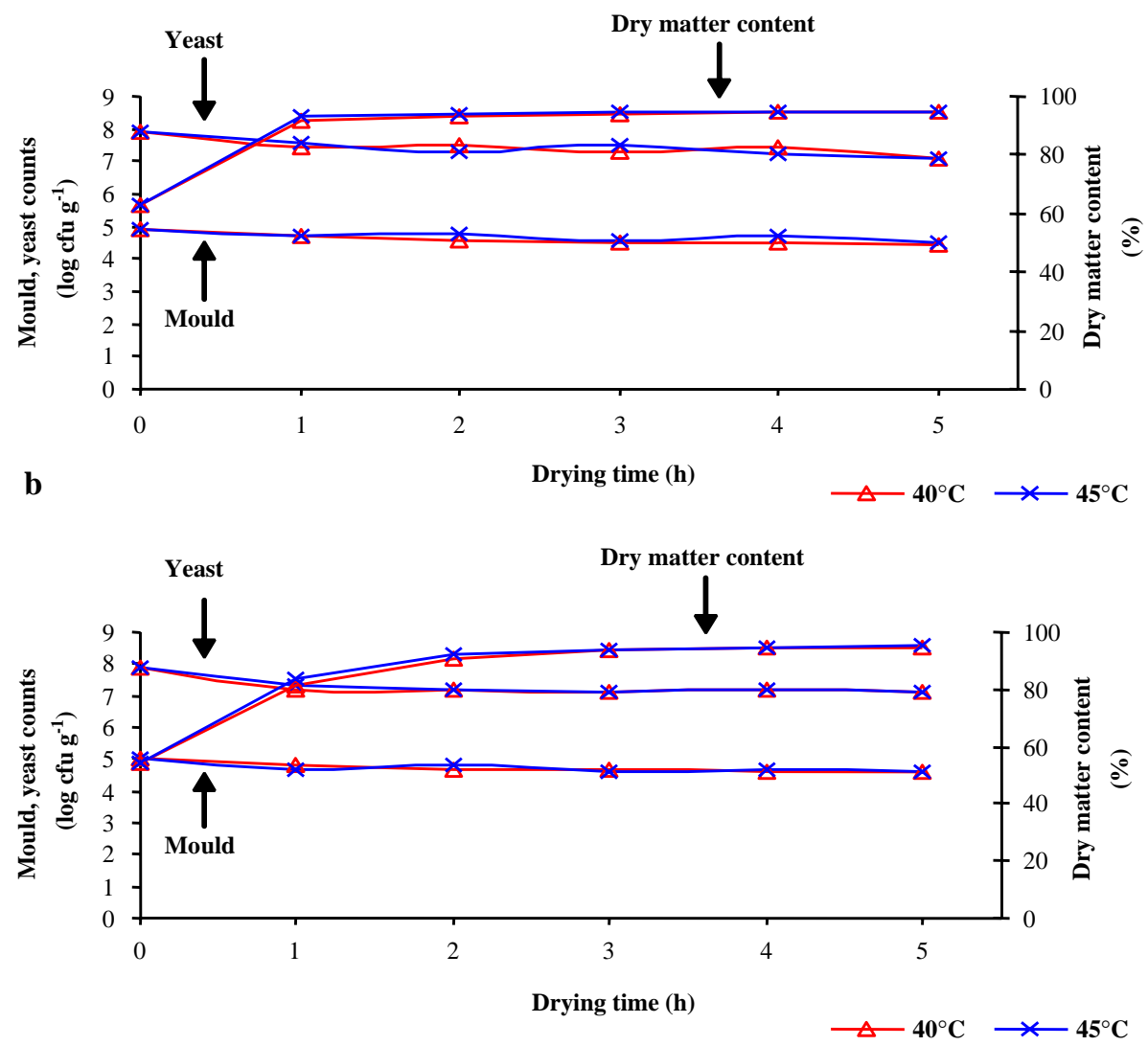

Fig. 5. The effect of drying time and temperature on dry matter content and fungal viability of starter dough granules of (a) $39 \%$ and (b) $47 \%$ initial moisture content.

ture). The viability of mould and yeast at the start of the storage period and after 1, 2 and 3 months of storage was determined by counting as shown in Table 5. At both storage temperatures and mixed flour moisture contents, mould and yeast counts remained almost the same.

The starter granules stored for 3 months were also tested for their winemaking performance. In Table 5, the winemaking performance and dry matter content of starter granules before and after 3 months of storage are compared. During 3 months of storage at $4{ }^{\circ} \mathrm{C}$, moisture levels had decreased slightly, whereas they had increased significantly after 3 months at $30{ }^{\circ} \mathrm{C}$. This shows that the packaging needs some further improvement in order to better protect the granules against high ambient humidity levels.

The alcohol levels in wine made with 3 months stored starter granules were significantly lower compared with those produced with freshly dried granules. Alcohol contents in wine from granules stored at $4{ }^{\circ} \mathrm{C}$ were significantly higher than the corresponding ones stored at $30{ }^{\circ} \mathrm{C}$. However, in general the alcohol contents produced from starter granules after 3 months of storage were still quite considerable: $15-18 \% \mathrm{v} / \mathrm{v}$ with granules stored at $4{ }^{\circ} \mathrm{C}$ and $10-14 \% \mathrm{v} / \mathrm{v}$ stored at $30{ }^{\circ} \mathrm{C}$. In addition, 3 months stored granules showed very good performance on other criteria for wine quality: good liquefaction after the first solid-state fermentation, and strong alcohol and sweet flavour of final product were observed. Based on the mould counts and the high levels of ${ }^{\circ}$ Brix, it can be concluded that the viability and enzyme activity of the mould in dry starter granules are quite stable during storage.

From this experiment it was concluded that not the mould, but rather the yeast activity is the limiting factor for shelf-life and stability of the starter granules. Further research will be needed into the possible roles of granule moisture content and gas permeability of packaging materials.

In conclusion, Fig. 6 summarizes the process diagram for the defined mixed-culture shelf-stable granulated starter for rice wine fermentation.

\subsection{Experimental wine and its sensory evaluation}

We compared commercially available rice wines ("Bien Hoa", "Can Tho" and "Go Den" brands) with wine produced with our experimental (referred to as "Experimental") dehydrated defined mixed-culture starter of $A$. rouxii and $S$. cerevisae. Three flasks of "Experimental" rice wine were taken at random for $\mathrm{pH}$ measurement and ethanol determination by the distillation method. The $\mathrm{pH}$ value and 
Table 5

Effect of storage of dry starter granules on their fungal viability, moisture content and winemaking performance

\begin{tabular}{|c|c|c|c|c|c|c|c|c|c|c|c|c|c|c|c|c|c|c|c|c|c|c|c|c|c|}
\hline \multicolumn{3}{|c|}{ Storage conditions } & \multicolumn{14}{|c|}{$\begin{array}{l}\text { Fungal viability in dry starter granules after } 0,1,2 \text { and } 3 \\
\text { months of storage }\end{array}$} & \multicolumn{9}{|c|}{$\begin{array}{l}\text { Moisture content and winemaking performance of dry starter granules } \\
\text { before }(t 0) \text { and after } 3 \text { months }(t 3) \text { of storage }\end{array}$} \\
\hline \multirow[t]{3}{*}{$\mathrm{MC}^{\mathrm{a}}(\%)$} & \multirow[t]{3}{*}{$T^{\mathrm{b}}\left({ }^{\circ} \mathrm{C}\right)$} & \multirow[t]{3}{*}{$t^{\mathrm{c}}(\mathrm{h})$} & \multicolumn{7}{|c|}{ Mould count (log cfu $\mathrm{g}^{-1}$ of starter) } & \multicolumn{7}{|c|}{ Yeast count (log cfu $\mathrm{g}^{-1}$ of starter) } & \multicolumn{3}{|c|}{ Moisture content $(\%)$} & \multicolumn{3}{|c|}{ Saccharification $\left({ }^{\circ}\right.$ Brix $)$} & \multicolumn{3}{|c|}{ Alcohol content $(\% \mathrm{v} / \mathrm{v}$} \\
\hline & & & \multirow[t]{2}{*}{$t 0^{\mathrm{d}}$} & \multicolumn{2}{|l|}{$t 1$} & \multicolumn{2}{|l|}{$t 2$} & \multicolumn{2}{|l|}{$t 3$} & \multirow[t]{2}{*}{$t 0$} & \multicolumn{2}{|l|}{$t 1$} & \multicolumn{2}{|l|}{$t 2$} & \multicolumn{2}{|l|}{$t 3$} & \multirow[t]{2}{*}{$t 0$} & \multicolumn{2}{|l|}{$t 3$} & \multirow[t]{2}{*}{$t 0$} & \multicolumn{2}{|l|}{$t 3$} & $t 0$ & $t 3$ & \\
\hline & & & & $4{ }^{\circ} \mathrm{C}^{\mathrm{e}}$ & $30^{\circ} \mathrm{C}$ & $4{ }^{\circ} \mathrm{C}$ & $30^{\circ} \mathrm{C}$ & $4{ }^{\circ} \mathrm{C}$ & $30^{\circ} \mathrm{C}$ & & $4{ }^{\circ} \mathrm{C}$ & $30^{\circ} \mathrm{C}$ & $4{ }^{\circ} \mathrm{C}$ & $30^{\circ} \mathrm{C}$ & $4{ }^{\circ} \mathrm{C}$ & $30{ }^{\circ} \mathrm{C}$ & & $4{ }^{\circ} \mathrm{C}$ & $30^{\circ} \mathrm{C}$ & & $4{ }^{\circ} \mathrm{C}$ & $30^{\circ} \mathrm{C}$ & & $4{ }^{\circ} \mathrm{C}$ & $30^{\circ} \mathrm{C}$ \\
\hline 39 & 40 & 0 & $4.9^{\mathrm{f}}$ & 4.7 & $-\mathrm{g}$ & 4.8 & - & 4.6 & - & 7.9 & 8 & - & 8 & - & 8.1 & - & 37.3 & 28.5 & - & 17 & 22 & - & 18.8 & 13.6 & - \\
\hline 39 & 40 & 1 & 4.7 & 4.5 & 4.6 & 4.4 & 4.6 & 4.3 & 4.4 & 7.4 & 7.4 & 7.3 & 7.4 & 7.2 & 7 & 7.1 & 8.3 & 7.1 & 9.2 & 16 & 22 & 22 & 19.7 & 16.2 & 13.6 \\
\hline 39 & 40 & 2 & 4.6 & 4.6 & 4.6 & 4.5 & 4.5 & 4.4 & 4.4 & 7.5 & 7.3 & 7.4 & 7.4 & 7.2 & 7.1 & 7.2 & 6.8 & 6 & 9 & 16 & 23 & 22 & 19.7 & 16.2 & 12 \\
\hline 39 & 40 & 3 & 4.5 & 4.4 & 4.5 & 4.6 & 4.4 & 4.5 & 4.4 & 7.3 & 7.2 & 7.2 & 7.2 & 7.1 & 7.1 & 7.2 & 6 & 6 & 9 & 17 & 22 & 21 & 19.7 & 17.9 & 13.6 \\
\hline 39 & 40 & 4 & 4.5 & 4.5 & 4.3 & 4.4 & 4.4 & 4.3 & 4.3 & 7.4 & 7.3 & 7.2 & 7.3 & 7.1 & 7.2 & 7.2 & 5.4 & 5.4 & 8.5 & 17 & 22 & 22 & 18.8 & 16.2 & 11.1 \\
\hline 39 & 40 & 5 & 4.4 & 4.3 & 4.2 & 4.3 & 4.2 & 4.3 & 4.2 & 7.1 & 7.2 & 7.1 & 7 & 7 & 7.1 & 7.1 & 5.2 & 5.5 & 8.3 & 16 & 21 & 21 & 19.7 & 16.2 & 12.8 \\
\hline 39 & 45 & 1 & 4.7 & 4.5 & 4.5 & 4.6 & 4.3 & 4.4 & 4.2 & 7.6 & 7.4 & 7.5 & 7.2 & 7.2 & 7.2 & 7 & 7 & 6.6 & 8.3 & 17 & 22 & 23 & 19.7 & 16.2 & 13.6 \\
\hline 39 & 45 & 2 & 4.8 & 4.5 & 4.7 & 4.6 & 4.5 & 4.4 & 4.4 & 7.3 & 7.3 & 7.4 & 7.3 & 7.1 & 7.2 & 7 & 5.8 & 5.7 & 8 & 16 & 23 & 22 & 19.7 & 17.1 & 11.1 \\
\hline 39 & 45 & 3 & 4.6 & 4.3 & 4.4 & 4.5 & 4.4 & 4.4 & 4.5 & 7.5 & 7.3 & 7.3 & 7.2 & 7.1 & 7.1 & 7 & 5.2 & 4.9 & 8.5 & 16 & 22 & 21 & 19.7 & 17.1 & 13.6 \\
\hline 39 & 45 & 4 & 4.7 & 4.5 & 4.5 & 4.3 & 4.3 & 4.3 & 4.4 & 7.2 & 7.1 & 7.2 & 7.1 & 7 & 7.1 & 7 & 5.1 & 5 & 8.7 & 17 & 21 & 21 & 18.8 & 16.2 & 12.8 \\
\hline 39 & 45 & 5 & 4.5 & 4.4 & 4.5 & 4.4 & 4.4 & 4.4 & 4.4 & 7.1 & 7.1 & 7.1 & 7 & 6.8 & 7 & 7 & 5 & 5 & 8.8 & 17 & 21 & 22 & 19.7 & 17.9 & 14.5 \\
\hline 47 & 40 & 0 & 5 & 4.8 & - & 4.7 & - & 4.7 & - & 7.9 & 8 & - & 8 & - & 8 & - & 45.6 & 34.7 & - & 17 & 22 & - & 19.7 & 15.4 & - \\
\hline 47 & 40 & 1 & 4.8 & 4.8 & 4.6 & 4.5 & 4.5 & 4.4 & 4.5 & 7.2 & 7.1 & 6.9 & 7 & 7 & 7 & 6.9 & 18.7 & 11.7 & 19.8 & 17 & 21 & 21 & 19.7 & 17.1 & 12 \\
\hline 47 & 40 & 2 & 4.7 & 4.6 & 4.6 & 4.5 & 4.2 & 4.4 & 4.2 & 7.2 & 6.9 & 6.8 & 6.7 & 6.9 & 6.9 & 7 & 9.5 & 8.5 & 10.5 & 17 & 21 & 21 & 19.7 & 17.1 & 12.8 \\
\hline 47 & 40 & 3 & 4.7 & 4.7 & 4.5 & 4.4 & 4.3 & 4.2 & 4.3 & 7.1 & 7.1 & 7 & 6.9 & 7 & 7.1 & 7 & 6.3 & 5.9 & 9.4 & 17 & 22 & 22 & 18.8 & 16.2 & 11.1 \\
\hline 47 & 40 & 4 & 4.6 & 4.6 & 4.5 & 4.5 & 4.3 & 4.4 & 4.1 & 7.2 & 7.1 & 7 & 7.1 & 6.8 & 6.9 & 6.8 & 5.6 & 5.7 & 9.3 & 17 & 21 & 22 & 19.7 & 17.9 & 12.8 \\
\hline 47 & 40 & 5 & 4.6 & 4.7 & 4.4 & 4.3 & 4.1 & 4.2 & 4.1 & 7.1 & 6.9 & 7 & 7 & 7 & 7 & 6.9 & 5.5 & 5.5 & 9.3 & 16 & 21 & 21 & 19.7 & 17.1 & 12.8 \\
\hline 47 & 45 & 1 & 4.7 & 4.6 & 4.6 & 4.3 & 4.2 & 4.2 & 4.2 & 7.3 & 7.1 & 6.8 & 6.9 & 6.9 & 6.9 & 6.7 & 16.2 & 9.2 & 18.8 & 17 & 22 & 22 & 18.8 & 16.2 & 12 \\
\hline 47 & 45 & 2 & 4.8 & 4.7 & 4.7 & 4.5 & 4.3 & 4.3 & 4.4 & 7.2 & 7 & 7 & 7.1 & 7 & 7 & 6.8 & 7.9 & 6.4 & 9.7 & 17 & 23 & 22 & 19.7 & 15.4 & 10.2 \\
\hline 47 & 45 & 3 & 4.6 & 4.6 & 4.5 & 4.2 & 4.1 & 4.2 & 4.2 & 7.1 & 7.1 & 7 & 6.8 & 6.8 & 6.9 & 7 & 6.1 & 6 & 9.4 & 17 & 22 & 23 & 19.7 & 16.2 & 11.1 \\
\hline 47 & 45 & 4 & 4.7 & 4.7 & 4.6 & 4.4 & 4.3 & 4.3 & 4.1 & 7.2 & 7 & 6.9 & 6.9 & 6.8 & 7 & 7 & 5.3 & 5.4 & 9.1 & 16 & 22 & 21 & 18.8 & 17.9 & 13.6 \\
\hline 47 & 45 & 5 & 4.6 & 4.5 & 4.5 & 4.2 & 4.3 & 4.1 & 4.1 & 7.1 & 6.8 & 6.9 & 7 & 7.1 & 7 & 6.9 & 5 & 5.1 & 8.9 & 17 & 22 & 22 & 19.7 & 17.1 & 12.8 \\
\hline
\end{tabular}

${ }^{a}$ Moisture content of dough.

${ }^{\mathrm{b}}$ Drying temperature.

${ }^{\mathrm{c}}$ Drying time.

${ }^{\mathrm{d}}$ Storage period in months.

e Storage temperature.

${ }^{\mathrm{r}}$ Values are means of duplicates.

${ }^{\mathrm{g}}$ Wet starter granules stored only at $4{ }^{\circ} \mathrm{C}$. 


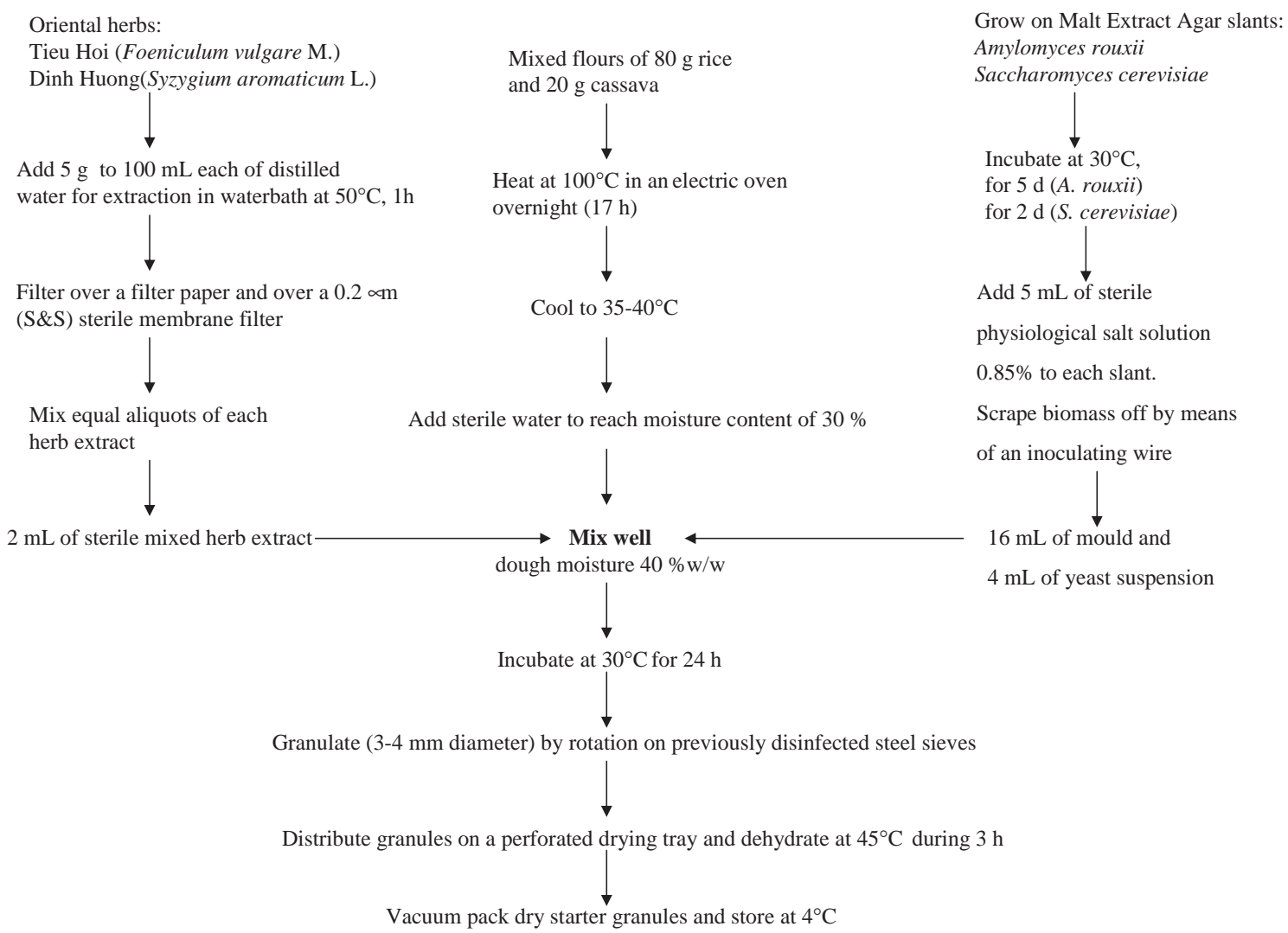

Fig. 6. Flow diagram for the laboratory-scale preparation of defined mixed-culture rice wine starter granules.

ethanol content of these three samples were identical, i.e. $\mathrm{pH}$ 3.9 and ethanol level at $20 \% \mathrm{v} / \mathrm{v}$. This indicates that the "Experimental" wine was representative for the wine obtained previously in small-scale defined mixed-culture fermentations.
Table 6 summarizes the results of sensory evaluation and the totals of weighted scores for the 4 wines. For each criterion the unweighted scores given by 20 panelists were averaged, multiplied with the respective weight factor and totaled.

Table 6

Sensory evaluation of experimental and commercial purple glutinous rice wines

\begin{tabular}{|c|c|c|c|c|c|c|c|c|c|}
\hline \multirow[t]{2}{*}{ Attributes } & \multirow[t]{2}{*}{$\mathrm{WF}^{\mathrm{a}}$} & \multicolumn{2}{|c|}{ "Experimental" } & \multicolumn{2}{|c|}{ "Go Den" } & \multicolumn{2}{|c|}{ "Bien Hoa" } & \multicolumn{2}{|c|}{ "Can Tho" } \\
\hline & & $\mathrm{UAS}^{\mathrm{b}}$ & WAS $^{\mathrm{c}}$ & UAS & WAS & UAS & WAS & UAS & WAS \\
\hline Colour and clearness & 0.8 & $3.95^{\mathrm{d}}$ & 3.16 & 2.38 & 1.90 & 4.3 & 3.44 & 3.15 & 2.52 \\
\hline Flavour & 1.2 & 3.90 & 4.68 & 2.45 & 2.94 & 3.0 & 3.60 & 3.35 & 4.02 \\
\hline Taste & 2.0 & 3.15 & 6.30 & 2.95 & 5.90 & 3.2 & 6.40 & 3.25 & 6.50 \\
\hline Total of weighted average scores & & & $14.14 \mathrm{a}^{\mathrm{e}}$ & & $10.74 \mathrm{~d}$ & & $13.44 \mathrm{~b}$ & & $13.04 \mathrm{c}$ \\
\hline \multicolumn{2}{|l|}{ Quality category } & \multicolumn{2}{|c|}{ Acceptable } & \multicolumn{2}{|c|}{ Not acceptable } & \multicolumn{2}{|c|}{ Acceptable } & \multicolumn{2}{|c|}{ Acceptable } \\
\hline Acceptability score & WF & $n^{\mathrm{f}}$ & Scores & $n$ & Scores & $n$ & Scores & $n$ & Scores \\
\hline Don't like at all & 1 & 1 & 1 & 3 & 3 & 0 & 0 & 2 & 2 \\
\hline Don't like & 2 & 2 & 4 & 8 & 16 & 5 & 10 & 3 & 6 \\
\hline So-so, just fair & 3 & 4 & 12 & 6 & 18 & 9 & 27 & 4 & 12 \\
\hline Like quite a bit & 4 & 7 & 28 & 2 & 8 & 3 & 12 & 5 & 20 \\
\hline Like very much & 5 & 6 & 30 & 1 & 5 & 3 & 15 & 6 & 30 \\
\hline Total & & 20 & 75 & 20 & 50 & 20 & 64 & 20 & 70 \\
\hline
\end{tabular}

${ }^{a}$ WF: weight factor.

${ }^{\mathrm{b}}$ UAS: unweighted average score $(n=20)$.

${ }^{c}$ WAS: weighted average scores.

${ }^{d}$ Values are means of 20 evaluation results by 20 examiners with duplicates.

e Values with different subscripts are statistically significant at the $95 \%$ confidence level.

${ }^{\mathrm{f}}$ Number of panelists. 
The scores given by the 20 panelists indicated that the panel was adequately sensitive and able to distinguish the different products; the same evaluation results or very slight differences were obtained with blind duplicates. The "Experimental" wine, "Bien Hoa" wine and "Can Tho" wine obtained significantly higher scores on all attributes, compared with "Go Den" wine mainly because of colour and clearness, but they scored also higher on flavour and taste. The "Experimental" wine obtained the best scores for flavour.

Although it is not a required item of the sensory evaluation of wine by Vietnamese standards, panel members were also asked to evaluate the samples according to their acceptability. As shown in Table 6, acceptability scores indicate that the panel members did not significantly prefer any of the wines, except that they did not appreciate the "Go Den" wine. This is one of the commercial rice wines produced at home-scale having rather high alcohol contents $(34 \% \mathrm{v} / \mathrm{v})$ because of the addition of distilled rice alcohol. Panelists commented that they did not appreciate its unnatural (artificial) colour and its high alcohol content. This is in good correspondence with the scores given for quality attributes. It must be noted here that several small-scale wine producers manipulate the quality of their wine; to reduce the cost of the required purple glutinous rice, this is blended with the-considerably cheaper-white glutinous rice and artificial red colour; poor saccharification and/or fermentation yields are masked by adding-cheapdistilled alcohol obtained from white glutinous rice. Apparently, experts able to detect the differences prefer the unadulterated wine.

In the Mekong Delta the development and upgrading of small-scale industry to add value to agricultural producefor instance by fermentation-is part of the Government policy aimed at improving the livelihood of Vietnamese people. Up till now, yield, flavour and acceptability of local rice wine prepared by traditional-uncontrolledmethods are variable and unpredictable. With the aim of a future transfer of know-how of biotechnological processes to wine starter manufacturers, we developed our "Experimental" wine at the laboratory scale. The results of our experiment indicate that this wine received adequate-acceptable-scores and received the highest scores for its flavour.

\section{Acknowledgements}

This research was financially supported by the Ministry of Foreign Affairs, The Hague, The Netherlands and the
International Foundation for Science, Stockholm, Sweden (grant number E/3322-1).

\section{References}

Battcock, M., \& Ali, S. A. (1993). Fermented fruits and vegetables. FAO Agricultural Services Bulletin, 134, 13-28.

Dung, N. T. P., Rombouts, F. M., \& Nout, M. J. R. (in press). Functionality of selected strains of moulds and yeasts from Vietnamese rice wine starters. Food Microbiology.

Hawker, L. E. (1966). Environmental influences on reproduction. In G. C. Ainsworth, \& A. S. Sussman (Eds.), Fungi: an advanced treaty (pp. 435-469). New York: Academic Press.

Hesseltine, C. W. (1983). Microbiology of oriental fermented foods. Annual Review of Microbiology, 37, 575-601.

Hieu, N. V. (1990). The role of the oriental medicaments in the traditional yeast preparation. Ha Noi: Trading University (in Vietnamese).

Holzapfel, W. H. (1997). Use of starter cultures in fermentation on a household scale. Food Control, 8, 241-258.

Loi, D. T. (2001). A textbook of medicinal plant and herb medicine in Viet Nam (8th edition). Ha Noi: Viet Nam Publisher (in Vietnamese).

Lotong, N. (1998). Koji. In B. J. B. Wood (Ed.), Microbiology of fermented foods (second edition). London: Blackie Academic \& Professional.

Luong, N. D. (1998). Production of fermented drinks (in Vietnamese). In N. D. Luong (Ed.), Microbiological technology (pp. 175-188). HCM City, Vietnam: Technology University.

McCleary, B. V., Bouhet, F., \& Driguez, H. (1991). Measurement of amyloglucosidase using $p$-nitrophenyl $\beta$-maltoside as substrate. Biotechnology Techniques, 5, 255-258.

Miambi, E., Guyot, J. P., \& Ampe, F. (2003). Identification, isolation and quantification of representative bacteria from fermented cassava dough using an integrated approach of culture-dependent and culture-independent methods. International Journal of Food Microbiology, 82, $111-120$.

Nout, M. J. R., \& Aidoo, K. E. (2002). Asian fungal fermented food. In H. D. Osiewacz (Ed.), The Mycota. Vol. X "Industrial applications" (pp. $23-47)$. Berlin: Springer-Verlag.

Phuc, N. H. (1998). The fermentation processes of traditional foods. HCM City, Vietnam: Agriculture Publisher (in Vietnamese).

Ray, B. (2001). Microorganisms used in food fermentation. In B. Ray (Ed.), Fundamental food microbiology (second edition) (pp. 109-118). Boca Raton, FL: CRC Press.

So, P. V., \& Nhuan, B. T. T. (1991). Analysis of cereals and food. Ha Noi: The Polytechnic University (in Vietnamese).

Steinkraus, K. H., Cullen, R. R., Pederson, C. S., Nellis, F. L., \& Gavitt, B. K. (1983). Handbook of indigenious fermented foods. New York: Marcel Dekker.

Thu, N. T. H. (1989). Food analysis by sensory evaluation techniques. Ha Noi: Technology \& Science Publishers (in Vietnamese).

Walker, G. M. (1998). Industrial alcohols. In G. M. Walker (Ed.), Yeast physiology and biotechnology (pp. 294-299). Chichester, UK: John Wiley \& Sons Ltd.

Zorba, M., Hancioglu, O., Genc, M., Karapinar, M., \& Ova, G. (2003). The use of starter cultures in the fermentation of boza, a traditional Turkish beverage. Process Biochemistry, 38, 1405-1411. 